Gut, 1962, 3, 336

\title{
The role of the pancreas in gastric secretion
}

\author{
B. N. CATCHPOLE 1 \\ From the Department of Surgery, University of Adelaide, Australia
}

EIITORIAL SYNOPSIS No significant difference has been detected in the acid gastric secretion of cats obtained by vagal stimulation before and after pancreatectomy.

The association of peptic ulceration, remarkably high acid secretion of the stomach, and pancreatic tumours was first described by Zollinger and Ellison (1955), who suggested that the pancreatic islets might play a part in normal gastric secretion. Recently Gregory, Tracy, French, and Sircus (1960, 1961) have made extracts from tumours of patients with the Zollinger-Ellison syndrome which they showed had properties similar to those of gastrin. If the pancreatic islets can cause tumours which profoundly influence secretion, and yet do not normally contain cells which have a role in the normal physiology of gastric secretion, they must be virtually unique amongst endocrine glands.

If such a factor is normally produced by the pancreas, Dragstedt (1955) has suggested on theoretical grounds that it is likely to be under nervous control. Furthermore Gillespie and Kay (1959, 1961) and Gelb, Baronofsky, and Janowitz (1961) have shown that the secretory response of the stomach to the maximal histamine test after vagotomy is greatly reduced; conceivably this might be due to the withdrawal of some essential factor for a full secretory response mediated by the vagus and originating in the pancreas.

These considerations led to the search, reported here, for a pancreatic factor under vagal control influencing gastric secretion.

\section{METHODS}

Cats were used in all experiments. The vagi were stimulated to induce gastric secretion of which the volume, $p \mathrm{H}$, and free acidity were measured. Collections before and after pancreatectomy, or splenectomy and nephrectomy as controls of operative trauma, were compared.

Adult animals were used of weights varying between $1 \frac{1}{2}$ and $5 \frac{1}{2} \mathrm{~kg}$. As it was thought initially that sex, pregnancy, and post-partum state influenced gastric secretion under vagal stimulation, the cats were largely matched in these respects in the experimental (pancreatectomy)

'Present address: Professorial Surgical Unit, St. Bartholomew's Hospital, London, E.C.1. and control (splenectomy and right nephrectomy) studies.

Anaesthesia was induced with ether and maintained by an intravenous injection, approximately $2 \mathrm{ml}$. per $\mathrm{kg}$. body weight given over five minutes, of a solution containing $20 \mathrm{~g}$. urethane and $2 \mathrm{~g}$. chloralose per $100 \mathrm{ml}$. This gave adequate anaesthesia for the six hours of the experiment.

The trachea was cannulated and the vagi dissected out through the incision which exposed the trachea. The almost invariably conjoined sympathetic and larger vagus nerves were gently separated from the carotid sheaths and the smaller sympathetic nerves stripped away. Thus $3 \mathrm{~cm}$. of vagus was exposed. A fine cotton thread was tied to its upper end and the nerve divided. This ligature was used to pull each nerve through an electrode carrier.

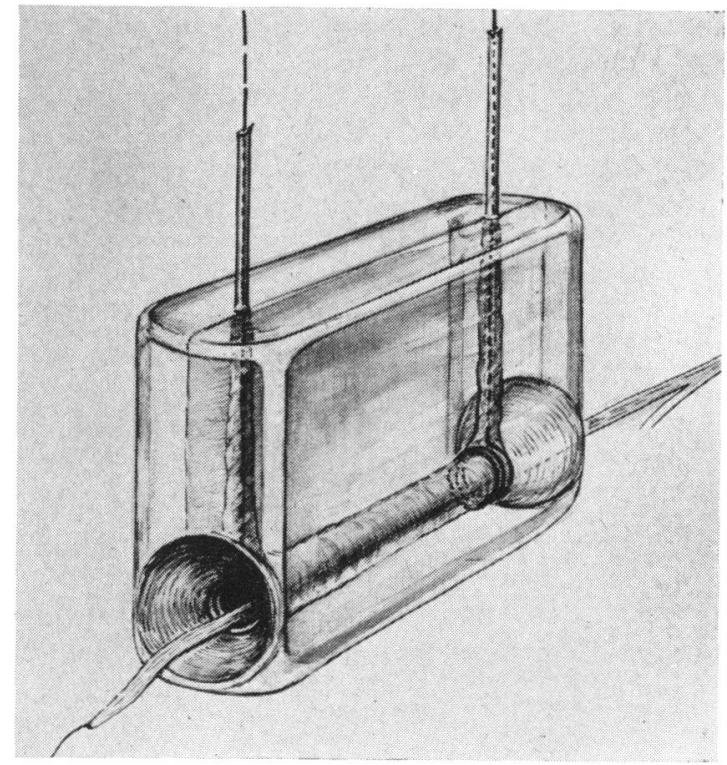

FIG. 1. A diagrammatic drawing of the electrode carrier (see text) showing the vagus nerve in position. This nerve usually occupied more of the tunnel than is indicated. 
The electrode carrier (Fig. 1) had been made by wrapping an 18 s.w.g. intravenous needle with two pieces of platinum wire over three circumferences, each insulated along their free end with nylon tubing. They were then positioned on the needle $1 \mathrm{~cm}$. apart and embedded in perspex. The needle was finally removed, the platinum contacts cleaned, and all sharp edges of perspex likely to kink the nerve removed.

Coincidently with the operative preparation described above, the upper abdomen was opened in the midline and the intra-abdominal temperature immediately taken by an electric thermometer; this temperature, taken approximately eight to 10 minutes after induction of anaesthesia, was assumed to be that of the animal normally. The pylorus was then tied off submucosally and an incision made in the pyloric antrum. A wide nylon cannula was tied into the stomach after the removal of any debris present. The abdomen was then closed around the cannula and the thermometer lead. The presence of a hair ball was usually associated with a gastritis and a poor secretory response to stimulation.

A femoral artery catheter was led to a Statham transducer recording on a Grass polygraph. This served to monitor the animal's blood pressure and pulse rate.

The animal was then transferred to a cradle with the cannula draining into a graduated tube. The electrode leads were connected to a Both stimulator via a contact breaker. Since vagal fatigue occurs rapidly as a result of continued stimulation, a revolving split drum was used to relay the stimulus alternately to each vagus for a period of two seconds while resting the other for a similar period. The stimulus consisted of sine waves, 50 cycles per second, 10 volts peak to peak.

Gastric specimens were collected every 15 minutes; the volume was recorded, $p \mathrm{H}$ measured, and the secretion titrated for free acidity using Töpfer's reagent as indicator, when of adequate volume.

All experiments reported were then performed as follows. With the animal in its support, collections were made with no disturbance for $\mathbf{3 0}$ minutes to allow recovery from the operative preparation and to permit the upper abdominal temperature to be brought back to that of the animal's body. This temperature was maintained at $37 \pm 1^{\circ} \mathrm{C}$. by general body infrared heating. Vagal stimulation was then carried out for one hour, blood pressure being monitored continuously, and the temperature recorded every 15 minutes when the samples were collected. In some cats, stimulation of the vagi produced a steady bradycardia; in most, however, it was apparent that stimulation of the left nerve had less effect in slowing the heart rate than did that of the right. The stimulation caused contraction of the stomach, as several drops were generally squeezed out as soon as this was begun. After an hour of stimulation, the animal was turned over and in the 'experimental' group pancreatectomy was performed by blunt dissection and pressure used to arrest oozing of blood; ligation of bleeding points was rarely necessary. The gastric cannula was not allowed to drain during this period and after closure of the abdomen accumulated juice was collected. The animal was then rested until two hours had elapsed after the end of the first period of stimulation. It was hoped that this would enable the temperature of the upper abdomen to return to normal, the effects of gastric manipulation to pass off, the mucosal cells to return to a normal resting state, and any pancreatic factor circulating in the blood and acting on the stomach to be dissipated.

After this period of rest the vagi were again stimulated for one hour with all the previous precautions: it was rare for the vagi to need readjustment in the electrode carriers but if one nerve was escaping from the stimulus it was gently pulled a little further into the carrier by its thread. At the conclusion of the hour's stimulation, three further specimens were collected and the experiment terminated.

The 'control' study was similar but the pancreas was left and the spleen and right kidney removed, two manoeuvres that were thought comparable to pancreatectomy in the extent of upper abdominal trauma caused.

Necropsy of the studied animals never showed retention of secretion in the stomach. In later animals, the stomach was excised, freed of fat and other attachments, and weighed.

\section{RESULTS}

GENERAL OBSERVATIONS The main data for examination are from 32 technically satisfactory experiments. Fifteen others were rejected for various reasons, e.g., unsatisfactory vagal stimulation during the first or second stimulatory periods, negligible

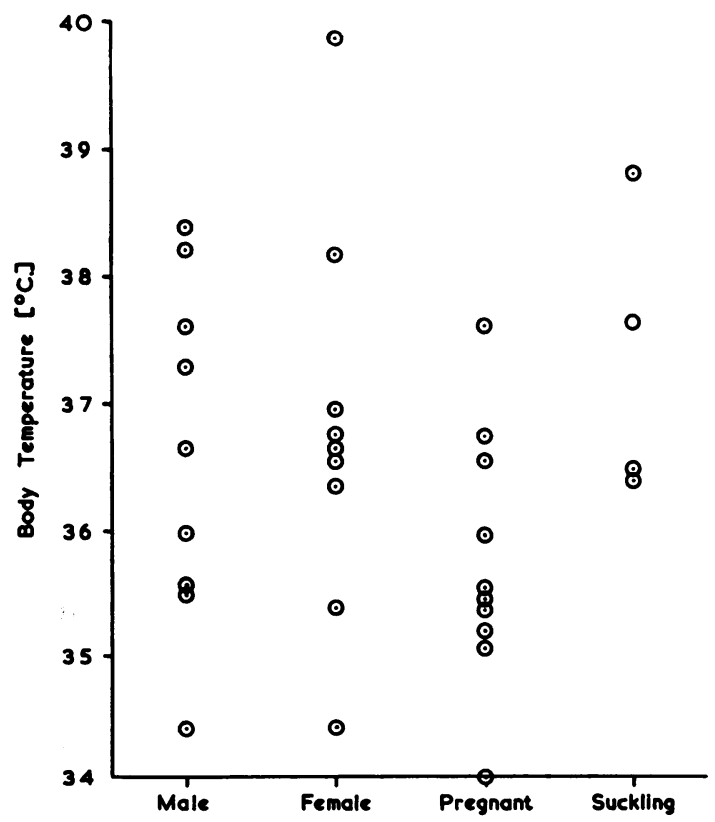

FIG. 2. The upper abdominal temperatures of the cats in the study. 'Female' refers to animals neither pregnant nor suckling. 
secretion, possibly as a result of gastritis, or collapse of the animal before the experiment had been completed. Since it is known that the secretory response of cats varies with sex and pregnant state (Ojha and Wood, 1950), animals were paired to a large extent in the control and experimental sections of the study, and the data presented accordingly. However, there is here no significant correlation between the secretory responses of the sexes.

The intra-abdominal temperatures taken immediately on laparotomy are presented in Figure 2 . The mean of the surprisingly wide range was $36 \cdot 5^{\circ} \mathrm{C}$.

VOLUME CHANGES IN SECRETION These data are presented in Table I. It can be seen that the secretion is minimal when vagal stimulation is not being applied (collections 1 to 2 and 13 to 14). The main secretory response (collections 3 to 6 and 15 to 18 inclusive) occurred during vagal stimulation. The mean arterial blood pressure in millimetres of mercury and pulse rate per minute while specimens 6 and 18 were collected are given as these were not the same during the stimulatory phases. The collections immediately after stimulation (collections 7 to 8 and 19 to 20) are also presented since these were of secretion produced largely during the vagal stimulatory phases.

Of the control animals, in only one (No. 4) was secretion similar before and after operation, in six secretion was greater, and in nine less. The blood pressure and pulse rate show no significant correlation with secretory response. After pancreatectomy only two animals (Nos. 19 and 31 ) had a secretory response approximately the same as before operation. Eleven, however, showed a fall and three a rise of secretion in the second stimulatory period

TABLE I

VOLUME OF GASTRIC SECRETION (ML.) DURING DIFFERENT COLLECTION PERIODS

\begin{tabular}{|c|c|c|c|c|c|c|c|c|c|c|c|}
\hline \multicolumn{2}{|l|}{ Cat } & \multicolumn{5}{|c|}{ Specimen } & \multicolumn{5}{|c|}{ Specimen } \\
\hline Sex & No. & $1-2$ & $3-6$ & $7-8$ & B.P. & Pulse & $13-14$ & $15-18$ & $19-20$ & B.P. & Pulse \\
\hline $\mathbf{M}$ & $\begin{array}{l}1 \\
2 \\
3 \\
4 \\
5\end{array}$ & $\begin{array}{l}0.6 \\
0.6 \\
0.7 \\
1.3 \\
0.7\end{array}$ & $\begin{array}{r}6 \cdot 0 \\
12 \cdot 5 \\
16 \cdot 5 \\
7 \cdot 2 \\
7 \cdot 1\end{array}$ & $\begin{array}{l}1 \cdot 3 \\
2 \cdot 3 \\
2 \cdot 1 \\
0.9 \\
1.3\end{array}$ & $\begin{array}{l}130 \\
135 \\
160 \\
100 \\
115\end{array}$ & $\begin{array}{l}135 \\
100 \\
135 \\
105 \\
110\end{array}$ & $\begin{array}{l}\text { Splene } \\
0.2 \\
0.5 \\
0.2 \\
0.1 \\
0.3\end{array}$ & $\begin{array}{c}\text { and } \mathrm{Rig} \\
4 \cdot 7 \\
10.9 \\
10 \cdot 5 \\
7 \cdot 3 \\
10 \cdot 7\end{array}$ & $\begin{array}{c}\text { phrector } \\
0.2 \\
1.8 \\
1.6 \\
1.0 \\
3.4\end{array}$ & $\begin{array}{r}125 \\
150 \\
155 \\
80 \\
90\end{array}$ & $\begin{array}{l}135 \\
150 \\
165 \\
120 \\
120\end{array}$ \\
\hline $\mathbf{F}$ & $\begin{array}{l}6 \\
7 \\
8 \\
9\end{array}$ & $\begin{array}{l}1.0 \\
1.6 \\
0.8 \\
1.1\end{array}$ & $\begin{array}{l}8 \cdot 3 \\
7 \cdot 3 \\
9 \cdot 7 \\
2 \cdot 7\end{array}$ & $\begin{array}{l}2.0 \\
1.0 \\
0.9 \\
0.8\end{array}$ & $\begin{array}{r}155 \\
145 \\
105 \\
95\end{array}$ & $\begin{array}{r}165 \\
115 \\
95 \\
85\end{array}$ & $\begin{array}{l}0.5 \\
0.8 \\
0.6 \\
0.2\end{array}$ & $\begin{array}{r}12.6 \\
11.8 \\
3.3 \\
16.8\end{array}$ & $\begin{array}{l}2.0 \\
0.8 \\
1.1 \\
1.5\end{array}$ & $\begin{array}{l}190 \\
135 \\
120 \\
115\end{array}$ & $\begin{array}{r}135 \\
110 \\
105 \\
85\end{array}$ \\
\hline $\mathbf{P}$ & $\begin{array}{l}10 \\
11 \\
12 \\
13\end{array}$ & $\begin{array}{l}3.3 \\
0.7 \\
1.3 \\
0.9\end{array}$ & $\begin{array}{l}10 \cdot 0 \\
18 \cdot 1 \\
18 \cdot 6 \\
14 \cdot 6\end{array}$ & $\begin{array}{l}2.5 \\
1.5 \\
1.5 \\
2.2\end{array}$ & $\begin{array}{l}115 \\
110 \\
125 \\
125\end{array}$ & $\begin{array}{l}165 \\
140 \\
195 \\
140\end{array}$ & $\begin{array}{l}1.5 \\
0.6 \\
0.2 \\
0.1\end{array}$ & $\begin{array}{l}1 \cdot 4 \\
1 \cdot 3 \\
9 \cdot 1 \\
6 \cdot 1\end{array}$ & $\begin{array}{l}0.1 \\
0.8 \\
3.0 \\
1.4\end{array}$ & $\begin{array}{l}125 \\
115 \\
100 \\
150\end{array}$ & $\begin{array}{l}165 \\
250 \\
165 \\
105\end{array}$ \\
\hline $\mathbf{S}$ & $\begin{array}{l}14 \\
15 \\
16\end{array}$ & $\begin{array}{l}4.1 \\
1.5 \\
1.5\end{array}$ & $\begin{array}{l}22.4 \\
10.0 \\
12.6\end{array}$ & $\begin{array}{l}3.0 \\
5.0 \\
1.3\end{array}$ & $\begin{array}{l}125 \\
130 \\
150\end{array}$ & $\begin{array}{l}130 \\
170 \\
120\end{array}$ & $\begin{array}{l}1.4 \\
0.5 \\
0.8\end{array}$ & $\begin{array}{r}8.5 \\
16.0 \\
13.8\end{array}$ & $\begin{array}{l}3.3 \\
1.7 \\
3.4\end{array}$ & $\begin{array}{l}105 \\
125 \\
140\end{array}$ & $\begin{array}{l}115 \\
150 \\
120\end{array}$ \\
\hline $\mathbf{M}$ & $\begin{array}{l}17 \\
18 \\
19 \\
20\end{array}$ & $\begin{array}{l}0.4 \\
1.7 \\
0.8 \\
1.3\end{array}$ & $\begin{array}{r}8.7 \\
8.2 \\
2.5 \\
37.8\end{array}$ & $\begin{array}{l}0.6 \\
0.5 \\
0.9 \\
2.4\end{array}$ & $\begin{array}{r}150 \\
115 \\
80 \\
110\end{array}$ & $\begin{array}{r}120 \\
85 \\
90 \\
105\end{array}$ & $\begin{array}{l}\text { Pancre } \\
0.2 \\
0.4 \\
0.1 \\
0.5\end{array}$ & $\begin{array}{r}m y \\
13.0 \\
6 \cdot 2 \\
2 \cdot 8 \\
19 \cdot 3\end{array}$ & $\begin{array}{l}2.6 \\
1.5 \\
0.8 \\
1.7\end{array}$ & $\begin{array}{r}130 \\
110 \\
80 \\
105\end{array}$ & $\begin{array}{r}115 \\
95 \\
75 \\
120\end{array}$ \\
\hline $\mathbf{F}$ & $\begin{array}{l}21 \\
22 \\
23 \\
24 \\
25\end{array}$ & $\begin{array}{l}0.8 \\
0.2 \\
0.3 \\
2.6 \\
1.0\end{array}$ & $\begin{array}{r}4 \cdot 0 \\
7 \cdot 2 \\
17 \cdot 4 \\
16 \cdot 3 \\
3 \cdot 4\end{array}$ & $\begin{array}{l}0.8 \\
1.5 \\
2.3 \\
1.0 \\
0.8\end{array}$ & $\begin{array}{r}80 \\
120 \\
150 \\
165 \\
110\end{array}$ & $\begin{array}{r}80 \\
100 \\
165 \\
180 \\
135\end{array}$ & $\begin{array}{l}0.1 \\
1.1 \\
0.8 \\
0.9 \\
0.6\end{array}$ & $\begin{array}{r}19.9 \\
4.6 \\
11.8 \\
5.5 \\
0.8\end{array}$ & $\begin{array}{l}1.6 \\
1.9 \\
1.1 \\
1.8 \\
0.1\end{array}$ & $\begin{array}{r}120 \\
130 \\
65 \\
155 \\
65\end{array}$ & $\begin{array}{l}105 \\
100 \\
120 \\
270 \\
105\end{array}$ \\
\hline $\mathbf{P}$ & $\begin{array}{l}26 \\
27 \\
28 \\
29\end{array}$ & $\begin{array}{l}2.1 \\
0.3 \\
\frac{-}{0.8}\end{array}$ & $\begin{array}{r}9.7 \\
6.3 \\
9.6 \\
12.0\end{array}$ & $\begin{array}{l}2.7 \\
0.9 \\
2 \cdot 3 \\
0.3\end{array}$ & $\begin{array}{r}100 \\
85 \\
90 \\
135\end{array}$ & $\begin{array}{r}130 \\
135 \\
90 \\
165\end{array}$ & $\begin{array}{l}0.5 \\
0.2 \\
0.3 \\
3.0\end{array}$ & $\begin{array}{l}5.8 \\
8.0 \\
7.4 \\
6.9\end{array}$ & $\begin{array}{l}3.7 \\
0.9 \\
1.2 \\
1.5\end{array}$ & $\begin{array}{l}80 \\
75 \\
80 \\
65\end{array}$ & $\begin{array}{r}145 \\
115 \\
90 \\
195\end{array}$ \\
\hline $\mathbf{s}$ & $\begin{array}{l}30 \\
31 \\
32\end{array}$ & $\begin{array}{l}0.5 \\
2.1 \\
0.5\end{array}$ & $\begin{array}{l}8.1 \\
7.8 \\
7.0\end{array}$ & $\begin{array}{l}1.4 \\
0.7 \\
0.8\end{array}$ & $\begin{array}{l}100 \\
135 \\
140\end{array}$ & $\begin{array}{r}75 \\
135 \\
165\end{array}$ & $\begin{array}{l}0.5 \\
0.8 \\
0.4\end{array}$ & $\begin{array}{l}7.1 \\
7.0 \\
3.5\end{array}$ & $\begin{array}{l}1.5 \\
2.1 \\
0.5\end{array}$ & $\begin{array}{l}100 \\
135 \\
135\end{array}$ & $\begin{array}{l}100 \\
150 \\
165\end{array}$ \\
\hline
\end{tabular}

Periods 3 to 6 and 15 to 18 are inclusive. B.P. is mean arterial blood pressure during collection periods 6 and 18 . Pulse is rate per minute at the same times. Sex of animal $M=$ male; $F=$ female, neither pregnant nor suckling; $P=$ pregnant; $S=$ suckling. 


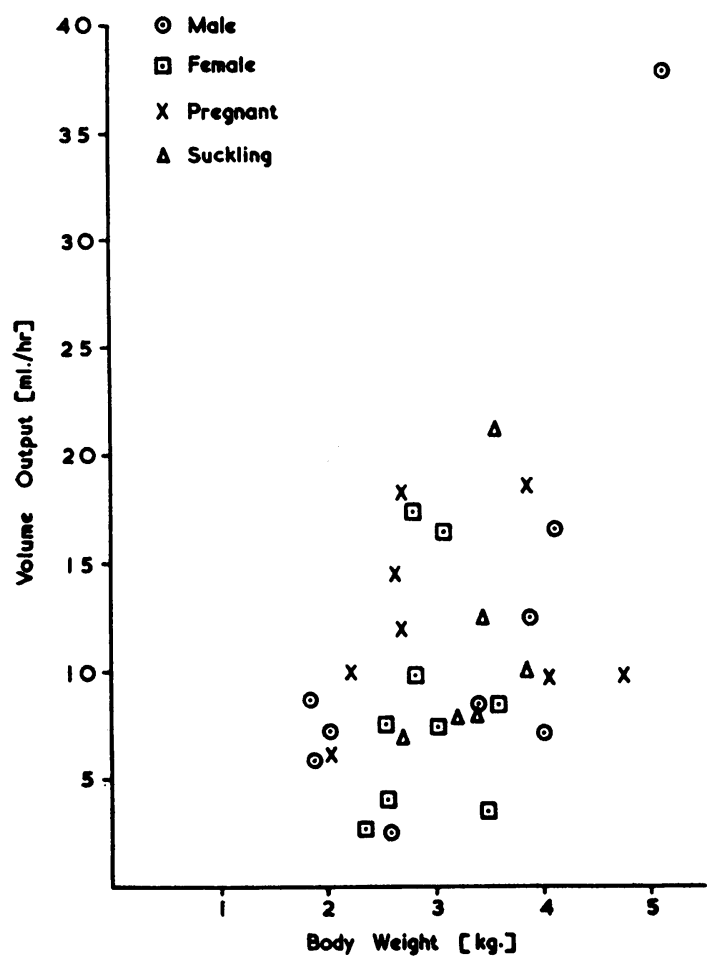

FIG. 3. Volume output of gastric secretion (specimens 3 to 6 inclusive) during vagal stimulation compared with body weight. compared with the first. In these, as in the control animals, blood pressure and pulse rate could not be correlated with the secretory response.

ACID OUTPUT Table II presents the responses during the study in terms of free acid secreted, where this was adequate in volume for titration. In general, secretion produced by vagal stimulation was watery and highly acid; a copious flow never had a high $p \mathrm{H}$. The flows of secretion were usually maximal in the second half of the stimulatory periods and these have been presented in addition to the total output during the whole stimulatory phase for purposes of comparison.

Almost invariably in both the control and experimental parts of the study, acid output fell or rose with the volume of gastric juice, but not necessarily in parallel with it. In animal No. 14, for example, although volume output declined to $38 \%$ of its previous level, acid output fell to $26 \%$. Furthermore, in animal No. 15, although total acid output during the hourly periods of stimulation rose with the increase in volume secreted, the rate at which acid was produced in the second half of the stimulatory period fell.

There is no significant difference between the volume of gastric secretion and acid produced before and after operation in the control and pancreatectomy groups. Mean volumes of gastric secretion in the second secretory periods calculated

TABLE II

ACID SECRETION (MEQ. PER HOUR) DURING COLLECTION PERIODS

\begin{tabular}{|c|c|c|c|c|c|c|c|c|c|c|c|c|c|c|c|}
\hline \multicolumn{2}{|l|}{ Cat } & \multicolumn{3}{|c|}{ Specimen } & \multicolumn{3}{|c|}{ Specimen } & \multicolumn{2}{|l|}{ Cat } & \multicolumn{3}{|c|}{ Specimen } & \multicolumn{3}{|c|}{ Specimen } \\
\hline $\operatorname{Sex}$ & No. & $3-6$ & pH & $5-6$ & $15-18$ & pH & $17-18$ & $\operatorname{Sex}$ & No. & $3-6$ & $p H$ & $5-6$ & $15-18$ & pH & $17-18$ \\
\hline & & & & & \multicolumn{3}{|c|}{$\begin{array}{l}\text { Splenectomy and } \\
\text { Nephrectomy }\end{array}$} & & & & & & \multicolumn{3}{|c|}{ Pancreatectomy } \\
\hline $\mathbf{M}$ & $\begin{array}{l}1 \\
3 \\
3 \\
4 \\
5\end{array}$ & $\begin{array}{l}0.53 \\
1.72 \\
1.94 \\
\overrightarrow{0.83}\end{array}$ & $\begin{array}{l}1 \cdot 3 \\
1 \cdot 1 \\
1 \cdot 1 \\
1 \cdot 1 \\
1 \cdot 1\end{array}$ & $\begin{array}{l}0 \cdot 64 \\
2 \cdot 37 \\
2 \cdot 08 \\
0 \cdot 78 \\
1 \cdot 13\end{array}$ & $\begin{array}{l}0.57 \\
1.35 \\
0.99 \\
- \\
1.45\end{array}$ & $\begin{array}{l}1 \cdot 2 \\
1 \cdot 1 \\
1.5 \\
1 \cdot 3 \\
1 \cdot 1\end{array}$ & $\begin{array}{l}0.63 \\
1.64 \\
1.14 \\
0.79 \\
1.58\end{array}$ & $\mathbf{M}$ & $\begin{array}{l}17 \\
18 \\
19 \\
20\end{array}$ & $\begin{array}{l}1.26 \\
0.88 \\
-5.60\end{array}$ & $\begin{array}{l}1.2 \\
1.2 \\
1.6 \\
1.1\end{array}$ & $\begin{array}{l}1.63 \\
1.08 \\
0.26 \\
6.41\end{array}$ & $\begin{array}{l}1.53 \\
0.51 \\
\frac{-}{2.65}\end{array}$ & $\begin{array}{l}1.3 \\
1.1 \\
1.5 \\
1 \cdot 2\end{array}$ & $\begin{array}{l}1.58 \\
0.70 \\
0.75 \\
3.23\end{array}$ \\
\hline $\mathbf{F}$ & $\begin{array}{l}6 \\
7 \\
8 \\
9\end{array}$ & $\begin{array}{l}1.04 \\
1.91 \\
-0.23\end{array}$ & $\begin{array}{l}1 \cdot 4 \\
1 \cdot 2 \\
2 \cdot 3 \\
1 \cdot 2\end{array}$ & $\begin{array}{l}1.07 \\
1.82 \\
0.78 \\
0.27\end{array}$ & $\begin{array}{l}1.60 \\
1.62 \\
-1.29\end{array}$ & $\begin{array}{l}1.4 \\
1.1 \\
2.0 \\
1.2\end{array}$ & $\begin{array}{l}2.05 \\
1.54 \\
\overline{2.36}\end{array}$ & $\mathbf{F}$ & $\begin{array}{l}21 \\
22 \\
23 \\
24 \\
25\end{array}$ & $\begin{array}{l}0.21 \\
\overline{2 \cdot 20} \\
2 \cdot 07 \\
-\end{array}$ & $\begin{array}{l}1 \cdot 1 \\
1 \cdot 4 \\
1 \cdot 1 \\
1 \cdot 3 \\
2 \cdot 8\end{array}$ & $\begin{array}{l}0.18 \\
0.60 \\
3 \cdot 15 \\
1.76 \\
-\end{array}$ & $\begin{array}{l}1.93 \\
\overline{1.53} \\
- \\
-\end{array}$ & $\begin{array}{l}1 \cdot 1 \\
1.4 \\
1.0 \\
1.4 \\
3.7\end{array}$ & $\begin{array}{l}1.81 \\
0.27 \\
1.81 \\
0.69 \\
-\end{array}$ \\
\hline $\mathbf{P}$ & $\begin{array}{l}10 \\
11 \\
12 \\
13\end{array}$ & $\begin{array}{l}0.62 \\
2.83 \\
-1.88\end{array}$ & $\begin{array}{l}2 \cdot 9 \\
1 \cdot 1 \\
1 \cdot 5 \\
1 \cdot 2\end{array}$ & $\begin{array}{l}0.62 \\
3.65 \\
4.36 \\
1.99\end{array}$ & $\bar{z}$ & $\begin{array}{l}3 \cdot 4 \\
2.0 \\
1.3 \\
1 \cdot 2\end{array}$ & $\begin{array}{l}- \\
\overline{2 \cdot 14} \\
0.74\end{array}$ & $\mathbf{P}$ & $\begin{array}{l}26 \\
27 \\
28 \\
29\end{array}$ & $\begin{array}{l}1.00 \\
0.83 \\
0.74 \\
1.51\end{array}$ & $\begin{array}{l}1.2 \\
1.3 \\
1.2 \\
1.3\end{array}$ & $\begin{array}{l}1 \cdot 28 \\
1 \cdot 29 \\
1 \cdot 15 \\
2 \cdot 71\end{array}$ & $\begin{array}{l}0.59 \\
1.06 \\
0.26 \\
0.92\end{array}$ & $\begin{array}{l}1 \cdot 2 \\
1 \cdot 3 \\
1 \cdot 3 \\
1 \cdot 3\end{array}$ & $\begin{array}{l}0.68 \\
1.60 \\
0.33 \\
1.30\end{array}$ \\
\hline $\mathbf{S}$ & $\begin{array}{l}14 \\
15 \\
16\end{array}$ & $\begin{array}{l}3.25 \\
1.20 \\
1.40\end{array}$ & $\begin{array}{l}1 \cdot 2 \\
1 \cdot 1 \\
1 \cdot 1\end{array}$ & $\begin{array}{l}3.65 \\
1.94 \\
1.55\end{array}$ & $\begin{array}{l}0.87 \\
1.87 \\
1.72\end{array}$ & $\begin{array}{l}1 \cdot 2 \\
1 \cdot 2 \\
1 \cdot 1\end{array}$ & $\begin{array}{l}0.93 \\
1.59 \\
1.98\end{array}$ & $\mathbf{S}$ & $\begin{array}{l}30 \\
31 \\
32\end{array}$ & $\begin{array}{l}0.80 \\
-\end{array}$ & $\begin{array}{l}1 \cdot 2 \\
1.0 \\
1.0\end{array}$ & $\begin{array}{l}1 \cdot 22 \\
1 \cdot 20 \\
0.77\end{array}$ & $\begin{array}{l}0.64 \\
-\end{array}$ & $\begin{array}{l}1 \cdot 2 \\
1 \cdot 1 \\
1 \cdot 2\end{array}$ & $\begin{array}{l}0.88 \\
0.89 \\
-\quad\end{array}$ \\
\hline
\end{tabular}




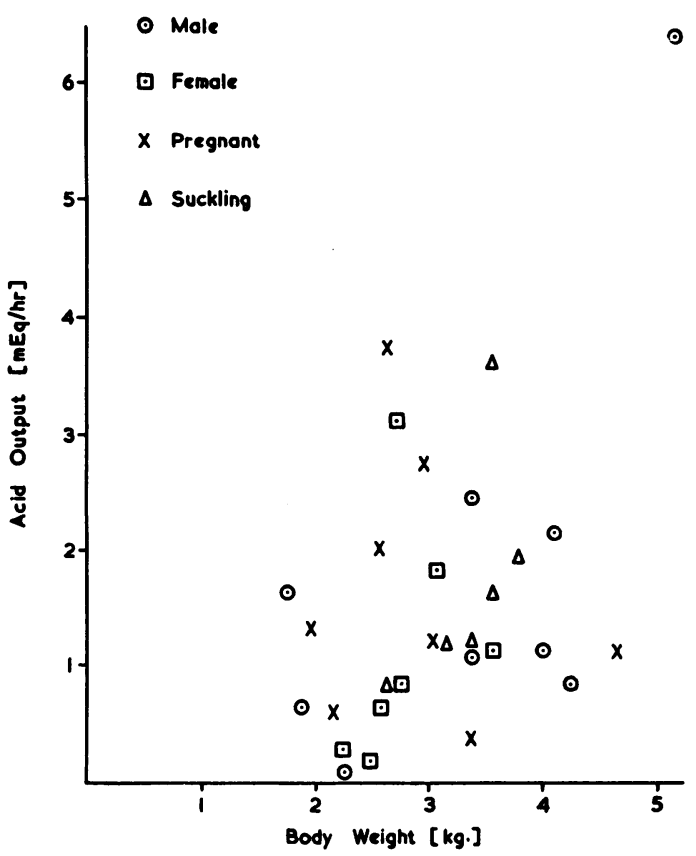

FIG. 4. Acid output during vagal stimulation calculated as mEquivalents hydrochloric acid per hour in collection periods 5 and 6 compared with body weight.

as percentages of the first periods are $117 \%$ S.D. \pm $140 \%$ in the control and $103 \%$ S.D. $\pm 107 \%$ in the pancreatectomy phases of the study. Corresponding calculations for mean acid secretions are $149 \%$ S.D. $\pm 215 \%$ and $147 \%$ S.D. $\pm 245 \%$. If the animals Nos. 9 and 21 showing gross changes are omitted, the mean values for volume output are $83 \%$ S.D. $\pm 35 \%$ and $76 \%$ S.D. $\pm 32 \%$ and for acid output $88 \%$ S.D. $\pm 46 \%$ and $81 \%$ S.D. $\pm 65 \%$ both respectively.

\section{DISCUSSION}

The programme used in this study proved to be fairly satisfactory. We had of course to do a certain amount of dissection in preparing the animal but this appeared to affect its general condition very little. Even the pancreatectomy and nephrectomy with splenectomy resulted in only a slight fall in blood pressure which quickly recovered. Vagal stimulation caused not only a flow of secretion but induced peristaltic activity which aided emptying of the stomach into the collecting apparatus. It often seemed that the peak flow of juice was reached before the end of the hour of stimulation but in other animals this did not seem to occur before stimulation was stopped. However, it was assumed that every animal acted as its own control in this regard.

It was thought that the varied secretory responses in the control part of the study might be due to an inadequacy of vagal stimulation in the second phase. It could be postulated that vagal fatigue was developing despite a continued vagal effect on the heart. However, examination of the pulse rates before and after operation did not suggest that a rise in pulse rate with a possibly associated diminution of gastric stimulation bore any direct relationship to the rate of secretion. If blood pressure is examined similarly, it is found that a relative fall in the second stimulatory phase was not necessarily accompanied by a fall in gastric output. Furthermore, a relative rise in blood pressure might equally well be associated with a fall in secretion.

The experimental data presented in this paper have not demonstrated the existence in the cat of a pancreatic factor which modifies gastric secretory output when this is induced by vagal stimulation. It is not supposed that this factor would necessarily play more than a minor role in a normal gastric response to ingested food, but it was thought that the experimental programme used here would be most likely to reveal its presence. It may be that gastric secretion encouraged by means other than simple vagal stimulation might be productive of a different conclusion and this study is currently being undertaken. Alternatively, another species of animal could be utilized.

Despite the arguments put forward in the introduction to this paper, the origin of the tumours in the syndrome described by Zollinger and Ellison might arise from ectopic cells capable of secreting a gastrin-like hormone. Many cases, however, have been described in the literature (Zollinger and Elliott, 1959) where islet cell hyperplasia not involving the alpha or beta cells has been noted; this proposition therefore seems unlikely. It would indeed be interesting to know if patients with duodenal ulcer also show pancreatic islet cell hyperplasia. Such a study would necessarily be laborious but in the absence of any clear-cut physiopathological cause for the development of duodenal ulcer, the suggestive indications of the syndrome discussed here merit further investigation.

This work was begun with the collaboration of Mr. I. E. Gillespie, and, with the encouragement of Professor A. W. Kay, continued in his and in Professor R. P. Jepson's laboratories. Many have assisted, in particular Mr. F. D. Naylor, Miss S. Winn, and Mr. G. Lehmann. Mr. W. Nolan has been responsible for the photography and Mrs. W. E. Towns kindly drew the electrode carrier. To all these colleagues I am grateful. 


\section{REFERENCES}

Dragstedt, L. (1955). Discussion. Ann. Surg., 142, 724-725.

Gelb, A. M., Baronofsky, I. D., and Janowitz, H. D. (1961). The effect of vagotomy and pyloroplasty on the maximal acid response to histamine, Gut, 2, 240-245.

Gillespie, I. E., and Kay, A. W. (1959). Personal communication.

,- (1961). Effect of medical and surgical vagotomy on the augmented histamine test in man. Brit. med. J., 1, 1557-1560.

Gregory, R. A., Tracy, H. J., French, J. M., and Sircus, W. (1960). Extraction of a gastrin-like substance from a pancreatic tumour in a case of the Zollinger-Ellison syndrome. Lancet, i, 1045-1048.
Grossman, M. I., Tracy, H. J., and Gregory, R. A. (1961). ZollingerEllison syndrome in a Bantu woman, with isolation of a gastrin-like substance from the primary and secondary tumors. II. Extraction of gastrin-like activity from tumors. Gastroenterology, 41, 87-91.

Ojha, K. N., and Wood, D. R. (1950). The inhibitory effect of stilboestrol on gastric secretion in cats. Brit. J. Pharmacol., 5, 389-394.

Zollinger, R. M., and Elliott, D. W. (1959). Pancreatic endocrine function and peptic ulceration. Gastroenterology, 37, 401-411. , R. M., and Ellison, E. H. (1955). Primary peptic ulcerations of the jejunum associated with islet cell tumors of the pancreas. Ann. Surg., 142, 709-726.

\section{The September 1962 Issue}

\section{THE SEPTEMBER 1962 ISSUE CONTAINS THE FOLLOWING PAPERS}

The pathology of chronic oesophagitis ROBERT J. SANDRY

Observations on idiopathic proctitis J. E. LENNARDJONES, G. W. COOPER, A. C. NEWELL, C. W. E. WILSON, and F. AVERY JONES

A double blind controlled trial of prednisolone-21phosphate suppositories in the treatment of idiopathic proctitis J. E. LENNARD-JONES, J. H. BARON, A. M. CONNELL, and F. AVERY JONES

The augmented histamine test in the differential diagnosis between ulcer and cancer of the stomach KAJ FISCHERMANN and $K$. H. KøSTER

Fluid and electrolyte disturbances in patients with long-established ileostomies N. D. GALlAGHER, D. D. HARRISON, and A. P. SKYRING

The case for total gastrectomy in multiple polyposis of the stomach R. A. ROXBURGH

Intestinal reticulosis as a complication of idiopathic steatorrhoea K. R. GOUGH, A. E. READ, and J. M. NAISH

Urinary xylose excretion in steatorrhoea MARGOT SHINER, B. J. VAKIL, and PAMELA B. WILCOX

Copies are still available and may be obtained from the PUBLISHING MANAGER, BRITISH MEDICAL ASSOCIATION, TAVISTOCK SQUARE, W.C.I., price 17s. 6D.

The results of operation in 46 cases of malformation of the anus and rectum VALENTINE A. J. SWAIN and S. M. TUCKER

Chronic painless pancreatitis s. J. M. GOULSTON and N. D. GALLAGHER

The gastric secretion of pepsin in man I. E. GILLESPIE and D. J. BOWEN

The role of seromucoid estimations in the investigation of haematemesis EWAN CAMERON, ALLAN CAMPBELL, and WILLIAM PLENDERLEITH

Studies on the stability of vitamin A in the stomach and small intestine OLIVER FITZGERALD, JAMES J. FENNELLY, and DANIEL J. HINGERTY

Interstitial emphysema of the caecum J. J. KAYBUTLER

An incomplete form of acanthosis nigricans I. B. SNEDDON and J. B. M. ROBERTS

A new direct-vision biopsy gastroscope ch. DEBRAY, P. HOUSSET, Et. MARTIN, J. P. BOURDAIS, and C. L. NICOLAIDIS 